\title{
Analisis Kepercayaan Konsumen Dan Dampaknya Terhadap Perilaku Pembelian Online Pada Website OLX Di Pekanbaru
}

\author{
AFRED SUCI $^{1}$; MASIRUN ${ }^{2}$; IKA BERTY APRILIYANI ${ }^{3}$ \\ Fakultas Ekonomi Universitas Lancang Kuning \\ Jln. Yos Sudarso KM 8 Rumbai \\ E-mail : afredsuci@unilak.ac.id ; masirun@unilak.ac.id ; ikabertyapriliyani@unilak.ac.id
}

\begin{abstract}
Internet technology development and the trend emergence of onlihe shops have given a numerous opportunity for micro and small business start up in Indonesia. This circumstance encourages new competition map in e-commerce industry. OLX as one of many e-commerce players, is facing tight pressures from competitors. This study, thus, becomes important to be conducted considering that there is still low consumers' trust for online shopping. This will obstruct the growth of micro and small industry in Indonesia because there is huge hesitation to purchase online among consumers. This study, therefore, was conducted to analyze consumers' trust and its impact to online buying behavior in OLX website. Respondents consist of 96 consumers, selected by using snowball sampling. Primary data was collected by using structured-questionaires. Data analyzed by descriptive analysis to measure the level of trust and online buying behavior, while inferential approach by using simple regression analysis operated to test the impact of trust to consumer's online buying behavior.
\end{abstract}

Keywords: $e$-Commerce, e-Trust and Online Buying Behavior

Transaksi online dapat terjadi secara cepat dan tidak lagi dibatasi oleh jam operasional pemasar konvensional. Kondisi ini membuat upaya pelaku pasar mikro dan kecil menjadi lebih mudah, fleksibel dan yang menggembirakan adalah lebih murah dalam menjadi start up bisnis atau mereka yang hendak memulai menjadi wirausahawirausaha mandiri. Dikatakan lebih murah karena dengan online trading maka hambatan modal untuk membuka toko menjadi tereliminir karena sisten online memungkinkan para pelaku usaha untuk tidak mengeluarkan modal dalam rangka membuka lokasi usaha. Salah satu dari sekian banyak portal online yang memberikan peluang kepada para pelaku usaha mikro dan kecil di Indonesia adalah OLX.com. Kelebihan situs ini dibandingkan operator lainnya adalah tidak diharuskan melakukan registrasi (pendaftaran) baik sebagai penjual maupun sebagai pembeli.

Fluktuasi pertumbuhan pendapatan OLX sepanjang 5 tahun terakhir, menunjukkan tidak pernah menyentuh angka lebih dari $\mathrm{Rp} 1,5$ triliun pertahun. Jika melihat tren pertumbuhan jumlah konsumen online yang cenderung meningkat, maka fluktuasi omset penjualan OLX tersebut tentunya tidak dapat dikatakan ideal. Rasionalnya adalah, kemudahan bertransaksi online di situs OLX mestinya berbanding lurus dengan kenaikan jumlah netter yang berbelanja online secara umum. Kondisi ini menggambarkan bahwa keputusan konsumen Indonesia membeli produk online dari OLX belum tumbuh sebagaimana yang diharapkan.

Dalam konteks pembelian online tentu aspek kepercayaan memainkan peranan yang cukup penting. Simamora (2009:11-14) menyatakan bahwa kepercayaan merupakan salah satu aspek psikologis yang bisa mempengaruhi keputusan konsumen. Saraswati dan Baridwan (2013) pada penelitiannya menyimpulkan bahwa kepercayaan 
merupakan faktor penting dan kritis dalam transaksi secara online. Meskipun pada penelitian Adityo (2011) menyimpulkan bahwa pengaruh kepercayaan cukup lemah dalam mempengaruhi keputusan pembelian online, namun pada penelitian Wardhani \& Saino (2013) sebaliknya justru menyimpulkan bahwa kepercayaan merupakan aspek paling dominan yang mempengaruhi keputusan pembelian secara online.

Permasalahan yang terjadi pada konsumen online adalah kurangnya kepercayaan pada keamanan sistem online sebagaimana yang biasa mereka lakukan melalui transaksi konvensional yang memungkinkan konsumen dan pemasar bertatap muka dan melihat langsung produk yang hendak dibeli. Hasil riset yang dilakukan Vela Asia tahun 2012 menunjukkan sebanyak satu dari empat pengguna internet di Indonesia berpikir dua kali sebelum berbelanja secara online karena buruknya kondisi pengiriman barang di Indonesia. Para shopper di daerah masih belum puas dengan kondisi pengiriman karena sering harus menunggu selama seminggu untuk kedatangan pesanannya, meskipun di situs belanja dijanjikan pengiriman tidak melebihi dari dua atau tiga hari (www.indotelk.com, 5 Juli 2013).

Munculnya ketidak-percayaan banyak netter terhadap belanja online selain karena faktor keterlambatan pengiriman, juga disebabkan karena barang-barang yang dikirim tidak sama atau rusak begitu diterima. Kekurangan informasi yang jelas dan longgarnya kesepakatan mengenai persyaratan jual beli online menyebabkan perselisihan cukup sering terjadi antara pembeli dan penjual online.

Sejumlah permasalahan yang banyak ditemukan pada konsumen online menunjukkan indikasi yang hampir serupa diantaranya: (a) informasi produk di situs tidak disampaikan secara jelas, sehingga barang yang diterima dipersepsikan tidak sama dengan yang iklankan di situs, (b) kebenaran atau orisinalitas produk sulit untuk dipastikan karena pembeli tidak melihat langsung barangnya, (c) pelayanan pembelian online di Indonesia masih buruk terutama pada aspek pengiriman, dan (d) pembayaran kerap bermasalah dan diragukan keamanannya. Karena faktorfaktor yang kurang dapat dipercaya itu pula, berdasarkan rating Alexa Traffic Rank memposisikan OLX di Indonesia hanya menempati urutan ke 14 dan di dunia bahkan urutan ke 758 dengan tingkat reputasi hanya 5,396 dari skala 1-10 sebagai situs rujukan tempat konsumen berbelanja online (http://alexa.com).

Penelitian ini menjadi penting untuk dilakukan dengan mempertimbangkan bahwa tingkat kepercayaan konsumen yang rendah pada situs belanja online OLX akan menghambat pertumbuhan usaha para pelaku usaha mikro dan kecil di Indonesia akibat konsumen merasa ragu-ragu untuk membeli produk yang diperdagangkan di situs tersebut. Oleh karena itu kajian mendalam yang spesifik membahas mengenai faktor kepercayaan dan dampaknya pada perilaku pembelian konsumen online pada situs belanja OLX perlu untuk dilakukan.

Berdasarkan uraian tersebut maka permasalahan yang hendak dijawab dari penelitian ini adalah: 1). Bagaimana tingkat kepercayaan konsumen pada situs belanja OLX di Pekanbaru? 2). Bagaimana perilaku pembelian konsumen Pekanbaru pada situs belanja OLX? 3). Bagaimana pengaruh kepercayaan terhadap perilaku pembelian konsumen Pekanbaru pada situs belanja OLX?

Kepercayaan merupakan faktor penting dan kritis dalam transaksi secara online. Faktor kepercayaan ini erat kaitannya dengan persepsi resiko karena seseorang tidak akan mempercayai suatu hal apabila merasa bahwa resiko yang akan dihadapinya cukup besar (Saraswati \& Baridwan, 2013). Dalam transaksi elektronik, faktor kepercayaan berdampak signifikan terhadap keputusan konsumen membeli secara online (Kim, et.,al., 2008; Wibowo \& Widodo, 2013; Saraswati \& Baridwan, 2013) bahkan pada penelitian

p.ISSN: $2407-800 X \quad$ e.ISSN: 2541-4356 
Wardani \& Saino (2013), disimpulkan bahwa kepercayaan merupakan faktor dominan yang mempengaruhi keputusan pembelian online, meskipun sebaliknya Metehan \& Yasmin (2011) menyimpulkan kepercayaan justru merupakan faktor paling lemah pengaruhnya terhadap keputusan pembelian online.

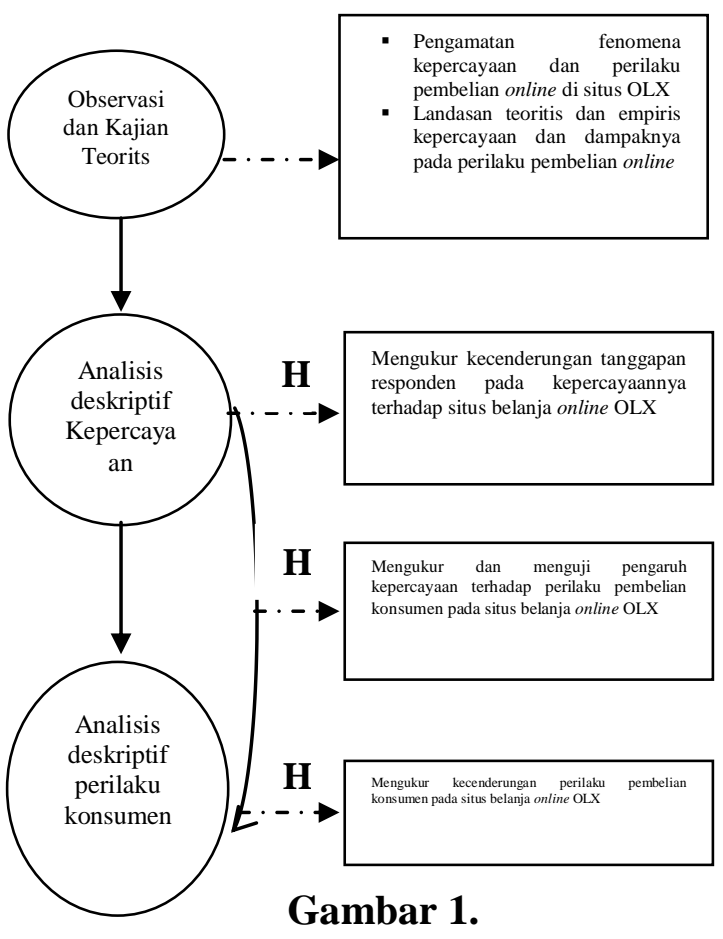

Kerangka Penelitian

Berdasarkan kerangka penelitian tersebut maka dapat dirumuskan hipotesis penelitian berikut ini:

H1 Diduga tingkat kepercayaan konsumen masih rendah pada situs belanja OLX

H2 Diduga perilaku pembelian konsumen masih rendah pada situs belanja OLX

H3 Diduga kepercayaan berpengaruh terhadap perilaku pembelian konsumen pada situs belanja OLX

\section{METODE}

Pengumpulan, pengolahan data-data serta penyajian hasil penelitian dilakukan di kota Pekanbaru. Secara garis besar, penelitian mengkaji secara deskriptif dua variabel yaitu Kepercayaan (X) sebagai variabel independen dan Perilaku Pembelian sebagai variabel dependen. Pengukuran tingkat kepercayaan diukur dari informasi produk, kebenaran produk, pelayanan pembelian, dan keberhasilan pembayaran (Utomo, et.,al., 2011). Sedangkan perilaku pembelian diukur dengan indikator: pengenalan kebutuhan, pencarian alternatif, evaluasi alternatif, pembelian dan evaluasi pasca pembelian (Schiffman \& Kanuk, 2008:8).

Populasi dalam penelitian ini adalah masyarakat Pekanbaru yang pernah membeli di situs OLX. Mengingat bahwa jumlah populasi tidak diketahui secara pasti, maka penetapan jumlah sampel dilakukan dengan mengikuti kaidah non probability sampling. Menurut Arikunto (2013:62) salah satu cara untuk mengetahui jumlah sampel non probability sampling adalah dengan menggunakan rumus sebagai berikut:

$$
\begin{aligned}
n=\left(\frac{Z \alpha / 2 \sigma}{e}\right)^{2} & =n \\
& =\left(\frac{(1,96) \cdot(0,25)}{0,05}\right)^{2} \\
& =96,04
\end{aligned}
$$

Dengan menggunakan rumusan tersebut maka diperoleh jumlah sampel minimum adalah 96 orang konsumen OLX di Pekanbaru yang dipilih berdasarkan teknik snowball sampling.

Hipotesis pertama dan kedua penelitian diuji dengan metode deskriptif kuantitatif. Alat analisis yang digunakan dengan menggunakan tabel distribusi frekuensi, distribusi silang dan analisis ratarata (mean).

Pengujian hipotesis ketiga dilakukan dengan analisis regresi linier sederhana. Analisis regresi adalah analisis yang mengukur pengaruh variabel bebas (independen) terhadap variabel terikat (dependen). Dikatakan linier karena setiap estimasi nilai diharapkan mengalami peningkatan atau penurunan mengikuti garis lurus.

\section{HASIL}

Mayoritas konsumen OLX yang menjadi responden pada penelitian ini

p.ISSN: $2407-800 X \quad$ e.ISSN: $2541-4356$ 
merupakan pelanggan wanita dibandingkan dengan pria. Konsumen wanita lebih menyukai berbelanja alat-alat kebutuhan rumah tangga dan fashion serta aksesoris, sedangkan konusmen pria lebih menyukai peralatan elektronik dan gaya hidup. Usia mayoritas responden relatif masih muda yaitu berkisar 25 tahun hingga 35 tahun yang kebanyakan berprofesi sebagai pegawai, baik yang di instansi pemerintah maupun swasta. Jika dilihat dari rata-rata pendapatan responden yang berada diantara Rp 2 juta hingga Rp 4 juta sebulan, bisa disimpulkan bahwa daya beli mayoritas responden belum tergolong tinggi.

Aktivitas belanja online yang dilakukan responden yang menjadi obyek penelitian berbeda-beda satu sama lain. Sebagian besar konsumen dalam penelitian ini jarang bertransaksi secara online di situs OLX. Namun demikian terdapat cukup banyak konsumen yang tergolong ke dalam frequent buyer dimana mereka sering melakukan transaksi online di situs OLX. Intensitasnya bisa 3 hingga 4 kali dalam satu bulan.

Dalam hal besaran nilai transaksi pembelian online persekali transaksi, terlihat bahwa mayoritas responden cukup berhatihati dengan membatasi nilai belanja tidak lebih dari Rp 300 ribu untuk setiap kali bertransaksi. Selain dari daya beli rata-rata responden yang memang tidak terlalu tinggi, faktor keamanan bertransaksi dengan nominal besar juga menjadi salah satu pertimbangan responden dalam membatasi transaksi online. Dengan pertimbangan keamanan ini pula mayoritas responden lebih menyukasi pembayaran via ATM setelah barang dipesan. Dalam jumlah yang relatif berimbang, banyak pula responden yang menyukai pola cash on delivery (bayar ditempat). Namun tentu saja pola seperti ini paling memungkinkan jika antara penjualan dan pembeli berada dalam satu lokasi yang relatif berdekatan.

Dalam konteks e-commerce, kepercayaan merupakan kemauan konsumen untuk terlibat dalam kegiatan yang berhubungan dengan online. Pada penelitian ini tingkat kepercayaan konsumen online diukur dengan menganalisis seberapa jauh konsumen mempercayai informasi produk, kebenaran produk, pelayanan pembelian dan keberhasilan pembayaran. Hasil analisis deskriptif aspek kepercayaan dapat disajikan sebagaimana tabel berikut:

Tabel 1. Tingkat Kepercayaan Konsumen OLX

\begin{tabular}{|l|c|c|}
\hline & Mean & $\begin{array}{c}\text { Kecenderungan } \\
\text { kepercayaan }\end{array}$ \\
\hline $\begin{array}{l}\text { Setiap informasi produk yang } \\
\text { didisplay di OLX sangat dapat } \\
\text { dipercaya }\end{array}$ & 3,2900 & Cukup tinggi \\
\hline $\begin{array}{l}\text { Spesifikasi setiap produk yang } \\
\text { dijual di OLX dapat diyakini } \\
\text { kebenarannya }\end{array}$ & 3,3300 & Cukup tinggi \\
\hline $\begin{array}{l}\text { Pelayanan proses pembelian dan } \\
\text { pengiriman barang via OLX } \\
\text { sangat memuaskan }\end{array}$ & 3,3700 & Cukup tinggi \\
\hline $\begin{array}{l}\text { Setiap prosedur pembayaran di } \\
\text { OLX dijamin mudah, aman dan } \\
\text { cepat }\end{array}$ & 3,7000 & Tinggi \\
\hline $\begin{array}{l}\text { Tingkat kepercayaan rata-rata } \\
\text { responden }\end{array}$ & 3,4225 & Tinggi \\
\hline
\end{tabular}

Sumber: Data olahan

secara rata-rata pada dasarnya tingkat konsumen memiliki tingkat kepercayaan yang tinggi, khususnya pada aspek prosedur pembayaran di OLX yang mudah aman dan cepat. Hal ini bisa diprediksi dari dominannya kecenderungan responden memilih cara pembayaran melalui ATM dan COD dibandingkan dengan metode kartu kredit atau kartu debit yang lebih beresiko. Implementasinya, banyak responden yang menghindari cara pembayaran tersebut. Selain itu, konsumen juga cenderung membatasi jumlah sekali transaksi maksimal $\mathrm{Rp} 300$ ribu untuk meminimalisir resiko. Kondisi-kondisi inilah yang menyebabkan tingkat kepercayaan pada aspek pembayaran menjadi tinggi, karena konsumen sudah melakukan proteksi berupa pembatasanpembatasan pada perilaku belanjanya.

Indikator yang cukup menjadi permasalahan pada rata-rata responden pada dasarnya terkait dengan kepercayaannya pada keakuratan informasi dan spesifikasi produk serta pelayanan pembelian yang dirasakan belum terlalu optimal. Pemesan hanya ditampilkan pajangan dan spesifikasi produk, namun belum melihat barangnya secara riil. Tidak jarang terjadi produk yang dikirimkan memiliki perbedaan, baik dari sisi ukuran, warna maupun bahan yang

p.ISSN: $2407-800 X \quad$ e.ISSN: $2541-4356$ 
digunakan sebagaimana yang tercantum di dalam situs. Yang paling sering terjadi adalah masalah perbedaan warna. Di dalam fotofoto produk yang dipajang di situs, seringkali warna terlihat lebih cerah karena efek fotografi, namun pada produk aslinya tidak sama persis dengan yang difoto. Sering terjadi perselisihan antara pemesan dengan pemilik situs akibat adanya perbedaanperbedaan seperti ini.

Dalam rangka memperdalam analisis mengenai tingkat kepercayaan konsumen OLX dengan melihatnya dari perbedaaan karakteristik belanja masingmasing responden, dilakukan pengujian Oneway Anova dengan kompilasi sebagaimana tabel berikut:

Tabel 2. Tingkat Kepercayaan Berdasarkan Perbedaan Karakteristik Belanja

\begin{tabular}{|l|c|l|}
\hline $\begin{array}{c}\text { Karakteristik } \\
\text { Belanja }\end{array}$ & $\begin{array}{c}\text { Nilai } \\
\text { sig. }\end{array}$ & \multicolumn{1}{|c|}{ Kesimpulan } \\
\hline Jenis kelamin & 0.807 & Tidak berbeda signifikan \\
\hline Intensitas belanja & 0.168 & Tidak berbeda signifikan \\
\hline Nilai transaksi & 0.001 & Berbeda signifikan \\
\hline Cara pembayaran & 0.226 & Tidak berbeda signifikan \\
\hline
\end{tabular}

Sumber: Data olahan

Tabel 2 menunjukkan bahwa tidak ada perbedaan tingkat kepercayaan yang signifikan meskipun terdapat perbedaan pada aspek jenis kelamin, intensitas belanja dan cara pembayaran pada responden. Baik konsumen pria maupun wanita sama-sama memiliki tingkat kepercayaan yang tinggi pada situs belanja online. Sementara itu, tingkat kepercayaan konsumen juga relatif sama baik pada konsumen yang sering berbelanja maupun yang jarang dan sangat jarang berbelanja online di situs belanja online OLX.

Perilaku atau karakteristik belanja konsumen yang membedakan tingkat kepercayaan konsumen adalah pada aspek nilai transaksi. Pada konteks ini menunjukkan bahwa pilihan cara pembayaran yang disukai konsumen bisa mempengaruhi tinggi rendahnya tingkat kepercayaan mereka pada situs OLX.

Pada penelitian ini, metode yang paling dirasakan aman oleh responden adalah melalui pembayaran via ATM dan COD (pembayaran di tempat). Dengan dua metode yang dianggap aman ini maka dapat ditemukan justifikasi meyakinkan mengapa tingkat kepercayaan konsumen, khususnya pada indikator keamanan pembayaran menjadi tinggi.

Dalam konteks e-commerce, perilaku Hasil analisis deskriptif aspek perilaku pembelian konsumen online dapat disajikan sebagaimana tabel berikut:

Tabel 3. Perilaku Konsumen OLX

\begin{tabular}{|l|c|c|}
\hline & Mean & $\begin{array}{c}\text { Kecenderungan } \\
\text { perilaku }\end{array}$ \\
\hline $\begin{array}{l}\text { Saya mengenali OLX sebagai tempat saya } \\
\text { membeli berbagai barang yang dibutuhkan }\end{array}$ & 3,2200 & Cukup baik \\
$\begin{array}{l}\text { Dari OLX saya bisa memperoleh berbagai } \\
\text { alternatif barang yang ingin dibeli }\end{array}$ & 3,5400 & Baik \\
$\begin{array}{l}\text { Berbagai alternatif di OLX memberikan saya } \\
\text { keleluasaan untuk mengevaluasi pilihan yang } \\
\text { tersedia }\end{array}$ & 3,2400 & Cukup baik \\
$\begin{array}{l}\text { Saya menjadikan OLX sebagai situs belanja } \\
\text { online yang utama }\end{array}$ & 3,2900 & Cukup baik \\
$\begin{array}{l}\text { Saya tidak pernah mengalami kekecewaan } \\
\text { setiap kali membeli dari OLX } \\
\text { Perilaku pembelian rata-rata responden }\end{array}$ & 3,0600 & $\begin{array}{l}\text { Cukup baik } \\
\text { Cukup baik }\end{array}$ \\
\hline
\end{tabular}

Sumber: Data olahan

Secara rata-rata pada dasarnya perilaku pembelian konsumen sudah cukup baik, khususnya pada aspek banyaknya alternatif pilihan produk yang bisa diperoleh konsumen dari situs OLX. Hal ini berkorelasi dengan cukup banyaknya responden yang mengaku sering melakukan pembelian melalui OLX, meskipun bukan merupakan pilihan yang mayoritas.

Indikator yang cukup menjadi permasalahan pada rata-rata responden pada dasarnya terkait dengan evaluasi pascapembelian, dimana masih ditemukan cukup banyak responden yang mengalami kekecewaan. Jika dikaitkan dengan deskripsi variabel kepercayaan, maka kekecewaan paling banyak terjadi karena terjadi ketidaksesuaian pada aspek informasi dan akurasi/spesifikasi produk yang dijanjikan dengan kenyataan yang dialami oleh pemesan.

Dalam rangka memperdalam analisis mengenai perilaku pembelian pada konsumen OLX dengan melihatnya dari perbedaaan karakteristik belanja masingmasing responden, dilakukan pengujian Oneway Anova dengan kompilasi sebagaimana tabel berikut: 
Tabel 4. Perilaku Pembelian Berdasarkan Perbedaan Karakteristik Belanja

\begin{tabular}{|l|c|c|}
\hline $\begin{array}{c}\text { Karakteristik } \\
\text { Belanja }\end{array}$ & $\begin{array}{c}\text { Nilai } \\
\text { sig. }\end{array}$ & \multicolumn{1}{c|}{ Kesimpulan } \\
\hline Jenis kelamin & 0.989 & Tidak berbeda signifikan \\
\hline Intensitas belanja & 0.701 & Tidak berbeda signifikan \\
\hline Nilai transaksi & 0.468 & Tidak berbeda signifikan \\
\hline Cara pembayaran & 0.666 & Tidak berbeda signifikan \\
\hline
\end{tabular}

Sumber: Data olahan

Tabel 4 menunjukkan bahwa tidak ada perbedaan perilaku pembelian yang signifikan meskipun terdapat perbedaan pada aspek jenis kelamin, intensitas belanja dan cara pembayaran pada responden. Baik konsumen pria maupun wanita sama-sama memiliki perilaku pembelian yang cukup baik. Sementara itu, perilaku pembelian konsumen juga relatif sama, baik pada konsumen yang sering berbelanja maupun yang jarang dan sangat jarang berbelanja online di situs OLX. Tinggi rendahnya nilai belanja sekali transaksi dan cara pembayaran yang disukai juga tidak memberikan perbedaan signifikan pada perilaku pembelian konsumen online OLX. Hal ini menunjukkan bahwa perilaku pembelian tidak ditentukan oleh perbedaan karakteristik pembelian.

Pengujian kepercayaan terhadap perilaku pembelian konsumen pada situs belanja online OLX dilakukan dengan menggunakan simple regression analysis dengan hasil sebagaimana gambar berikut:

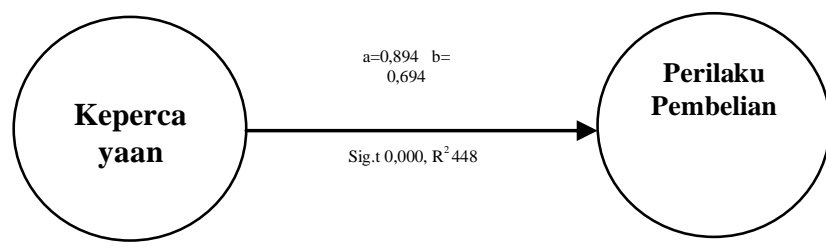

Gambar 2.

Pengaruh Kepercayan Terhadap Perilaku Pembelian Online

Gambar 2 memperlihatkan nilai koefisien konstanta, dan koefisien regresi, signifikansi dan koefisien determinasi yang dapat ditafsirkan sebagai berikut:

a) Nilai konstanta (a) menunjukkan bahwa jika kepercayaan diasumsikan konstan maka perilaku pembelian responden memiliki nilai 0,894 . Nilai ini muncul dari kondisi kepercayaan yang sudah terbentuk pada diri konsumen serta kemungkinan pengaruh dari factor-faktor lain (epsilon) yang tidak ikut dibahas pada penelitian ini.

b) Nilai koefisien regresi (b) menunjukkan bahwa jika terjadi peningkatan kepercayaan sebesar 1 poin maka akan terjadi peningkatan pada perilaku pembelian sebesar 0,694. Peningkatan yang terjadi pada perilaku pembelian relatif signifikan mengingat bahwa nilai signifikansi (sig.t) yang diperoleh adalah $0,000<\alpha 0,05$. Dengan demikian maka semakin tinggi tingkat kepercayaan konsumen maka dapat mendorong perilaku pembeliannya secara positif dan signifikan.

Nilai koefisien determinasi $\left(\mathrm{R}^{2}\right)$ 0,448 menunjukkan bahwa perilaku pembelian konsumen pada situs belanja OLX sebesar $44,8 \%$ dipengaruhi oleh seberapa besar tingkat kepercayaan yang dimilikinya pada situs yang bersangkutan.

\section{PEMBAHASAN}

Hasil analisis deskriptif menyimpulkan bahwa tingkat kepercayaan konsumen pada situs belanja online OLX relatif tinggi. Dengan hasil ini maka disimpulkan bahwa hipotesis pertama penelitian yang menyatakan bahwa tingkat kepercayaan konsumen masih rendah, menjadi tidak dapat diterima. Adapun hipotesis kedua penelitian yang menyatakan bahwa perilaku pembelian masih rendah, juga tidak dapat diterima mengingat hasil analisis deskriptif menyimpulkan bahwa perilaku pembelian sudah cukup tinggi, meskipun belum optimal.

Tidak diterimanya hipotesis pertama dan kedua menunjukkan bahwa ada sinyal yang cukup positif dari masyarakat kota Pekanbaru terhadap keberadaan dan keberlanjutan situs belanja OLX ditengah persaingan dengan online marketplace lainnya yang beroperasi di Indonesia, baik itu yang bersifat lokal, nasional maupun global. Kepercayaan responden pada situs belanja OLX cukup terjaga karena 
responden pada dasarnya sudah memproteksi karakteristik belanjanya dengan membatasi frekuensi (intensitas), nilai transaksi dan juga metode pembayaran yang dirasakan paling aman. Sementara perilaku pembelian menjadi cukup tinggi dikarenakan responden menemukan banyak pilihan/alternatif produk di situs belanja OLX, dimana konsumen bisa memilih lokasi penjualan yang terdekat dengannya untuk meminimalisir resiko pembelian. Dengan lokasi yang berdekatan, maka konsumen bisa leluasa untuk melihat produk pesanan dan melakukan pembayaran ditempat (COD).

Sedangkan hipotesis ketiga penelitian bisa diterima, karena hasil analisis regresi menyimpulkan bahwa kepercayaan berpengaruh positif dan signifikan terhadap perilaku pembelian. Semakin tinggi kepercayaan konsumen, semakin besar kemungkinan perilaku pembeliannya. Sebaliknya, perilaku pembelian konsumen akan melemah seiring dengan menurunnya tingkat kepercayaan pada situs belanja OLX. Tingkat kepercayaan yang tinggi dari responden pada akhirnya menyebabkan perilaku pembeliannya menjadi cukup tinggi.

Kepercayaan yang tinggi dari konsumen OLX, berdasarkan hasil analisis deskriptif disebabkan karena konsumen sudah melakukan proteksi resiko dengan membatasi intensitas dan nilai transaksi serta metode pembayaran yang paling aman. Kondisi ini sejalan dengan apa yang dinyatakan oleh Saraswati \& Baridwan (2013) bahwa faktor kepercayaan erat kaitannya dengan persepsi resiko. Kesimpulan penelitian ini juga memperkuat sejumlah peneliti sebelumnya bahwa keputusan pembelian konsumen ditentukan secara signifikan oleh aspek kepercayaan (Kim, et.al., 2008; Wibowo \& Widodo, 2013; Saraswati \&Baridwan, 2013). Namun demikian jika dibandingkan dengan penelitian Metehan \& Yasmin (2011) maka kesimpulan ini cukup bertolak belakang mengingat hasil penelitiannya tidak menemukan adanya pengaruh signifikan dari faktor kepercayaan terhadap keputusan pembelian online.
Implikasi hasil penelitian ini mendorong perlunya upaya penguatan kepercayaan dari masyarakat agar kecenderungan perilaku belanja online yang kuat bisa didapatkan. Akurasi informasi dan kebenaran spesifikasi serta jaminan pelayanan pembelian yang masih menjadi kelemahan pada aspek kepercayaan pada penelitian ini perlu untuk dilakukan perbaikan.

\section{SIMPULAN}

Berdasarkan temuan hasil dan pembahasan hasil penelitian disimpulkan bahwa konsumen memiliki tingkat kepercayaan yang tinggi pada situs belanja OLX. Sementara itu perilaku pembelian konsumen dari situs belanja OLX relatif sudah cukup tinggi. Dengan demikian maka bisa disimpulkan bahwa semakin tinggi kepercayaan yang dimiliki konsumen, semakin tinggi perilaku pembeliannya pada situs belanja OLX.

\section{DAFTAR RUJUKAN}

Adityo, Benito. 2011. Analisis Pengaruh Kepercayaan, Kemudahan dan Kualitas Informasi Terhadap Keputusan Pembelian Secara Online di Situs Kaskus. Penelitian Dosen, diakses dari $\underline{\text { http://www.eprints.undip.ac.id }}$

Arikunto, Suyono. 2013. Cara Dahsyat Membuat Skripsi. Jaya Star Nine, Madiun

Kim, D.J., D.L. Ferrin dan H.R. Rao. 2008. A Trust-based Consumer Decisionmaking Model in Electronic Commerce: The Role of Trust, Perceived Risk and Their Antecedents. Science Direct, 44, 544-564

Metehan, Tolon dan Z.A. Yasemin. 2011. The Effect of Web Vendor Trust on Turkish Online Shoppers Buying Behavior. Australian Journal of

p.ISSN: $2407-800 X \quad$ e.ISSN: 2541-4356 
Business and Management Research, 1(6), 87-96

Saraswati P. dan Z. Baridwan, 2013. Penerimaan Sistem E-Commerce: Pengaruh Kepercayaan, Persepsi Manfaat dan Persepsi Resiko. Jurnal Ilmiah Mahasiswa FEB Universitas Brawijaya, diakses dari http://jimfeb.ub.ac.id

Schiffman, Leon dan L.L. Kanuk. 2008. Perilaku Konsumen. Indeks, Jakarta

Simamora, Bilson. 2009. Panduan Perilaku Konsumen. Gramedia Pustaka Utama, Jakarta
Wardani, Ni Made S.K. dan Saino, 2013. Pengaruh Citra Toko dan Kepercayaan Terhadap Keputusan Pembelian Online Pada Ndy Shop. Jurnal Ilmu Manajemen, 1(2), 443452

Wibowo,A. dan F. Widodo. 2013. Peran Kepercayaan Terhadap Perilaku Pembelian dan Loyalitas Pelanggan Telkom Speedy di Surabaya. Tesis Universitas Jember

http://www.alexa.com. 2016

http://www.indotelk.com. 5 Juli 2013 